\title{
Impact of Common Kingfisher on a salmon population during the nestling period in southern England
}

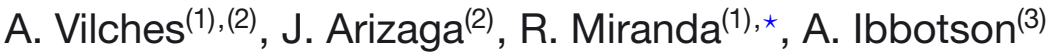 \\ Received March 1, 2013 \\ Revised May 14, 2013 \\ Accepted June 1, 2013
}

Key-words:

Atlantic salmon,

bird

conservation,

fish-eating

predator,

fish

management,

River Frome

\section{ABSTRACT}

The effect of fish-eating birds on their fish-prey populations has been a matter of concern to conservationists, anglers and fishery interests, especially when both bird and fish species have conservation status and are afforded some protection by law. Understanding the predator-prey interactions will assist in managing these potential conflicts. This situation could arise with the Common Kingfisher (Alcedo atthis), whose range covers many important Atlantic salmon (Salmo salar) rivers. In order to increase our knowledge on predator-prey interactions between these species, we collected data on the diet and feeding rates of a kingfisher population breeding in an Atlantic salmon river in southern England (River Frome). Results showed that, during nestling period, kingfishers provided a mean of 62 fish per day to the nest and that the mean salmon intake was $2.5 \%$ of the entire diet, which is equivalent to 86 salmon parr consumed by each kingfishers pair for the entire breeding period (assuming 2.2 broods/pair/year). The total 0-group salmon population in the River Frome was 63900 . The estimated loss of 0 -group salmon parr to the kingfishers over one season was $0.8 \%$, thus supporting the view that the kingfisher has a negligible biological impact over this salmon population.

\section{RÉSUMÉ}

Impact du martin-pêcheur d'Europe sur une population de saumons pendant la période de nidification dans le sud de l'Angleterre

Mots-clés : saumon atlantique, conservation des oiseaux, prédateur de poissons, gestion piscicole, rivière Frome
L'effet des oiseaux piscivores sur les populations de poissons-proies est un sujet de préoccupation pour les écologistes, les pêcheurs de loisirs et professionnels, en particulier lorsque les deux espèces d'oiseau et de poisson ont un statut de conservation et jouissent d'une certaine protection par la loi. Comprendre les interactions prédateur-proie va aider à gérer ces conflits potentiels. Cette situation pourrait se produire avec le martin-pêcheur d'Europe (Alcedo atthis), dont l'habitat occupe beaucoup d'importantes rivières à saumon Atlantique (Salmo salar). Afin d'accroitre nos connaissances sur les interactions prédateur-proie entre ces espèces, nous avons recueilli des données sur l'alimentation et le rythme d'alimentation d'une population nicheuse de martin-pêcheur dans une rivière à saumon Atlantique dans le sud de l'Angleterre (rivière Frome). Les résultats ont montré que,

(1) Department of Environmental Biology, University of Navarra, Irunlarrea 1, 31080 Pamplona, Spain

(2) Department of Ornithology, Aranzadi Sciences Society, Zorroagagaina 11, 20014 San Sebastián, Spain

(3) Salmon and Trout Research Centre, Game and Wildlife Conservation Trust, The River Laboratory, East Stoke, Wareham, Dorset BH20 6BB, England

*Corresponding author: rmiranda@unav.es 
pendant la période de nidification, les martins-pêcheurs ont fourni une moyenne de 62 poissons par jour au nid et que l'apport moyen de saumon était de 2,5\% de l'ensemble du régime, ce qui équivaut à 86 tacons consommés par chaque couple de martins-pêcheurs pour l'ensemble de la période de nourrissage (en supposant 2,2 jeunes / couple / an). La population totale de saumon de l'année dans la rivière Frome était de 63900 . La perte estimée de tacons due aux martins-pêcheurs sur une saison était de $0,8 \%$, soutenant ainsi l'idée que le martin-pêcheur a un impact biologique négligeable sur cette population de saumons.

\section{INTRODUCTION}

The effect of fish-eating birds on their fish-prey populations has been a matter of concern to anglers and fisheries (Russell et al., 1996; Cowx, 2003). The presence of these birds on a commercial or recreational fishery usually results in conflict between the fishery interests and those interested in protecting birds (Russell et al., 1996). Amongst the birds, the Great cormorant (Phalacrocorax carbo) has received the greatest attention and generates most debate (Britton et al., 2003; Winfield et al., 2003; Čech and Vejrík, 2011), although the impact of other birds such as goosanders (Mergus spp.), grebes (family Podicipedidae) or herons (family Ardeidae) has been also studied (Wilson et al., 2003; see Cowx, 2003 for a review). Studies have mainly focussed on species with fishery interest such as salmonids or cyprinids (Feltham, 1990; 1995; Britton et al., 2003), although in some cases these have also dealt with protected fish such as Whitefish (Coregonus lavaretus) and the Atlantic salmon. (Salmo salar) (Carss and Marquiss, 1999; Winfield et al., 2003).

European Atlantic salmon stocks are seen as under threat, in particular from recent and future changes to climate (Friedland et al., 1993). In many rivers along the south coast Atlantic salmon stocks fell by as much as 70\% in the 1990's and hence there has been increasing pressure to understand potential threats to individual populations at all life stages. Atlantic salmon is a Biodiversity Action Plan (BAP) species (see for details the European Habitats Directive), so it is afforded a substantial environmental protection. It also has a remarkable economic and cultural value.

In the case of River Frome basin (Dorset, southern England) large fish-eating birds such as cormorants, goosanders or herons are scarce or almost absent (Hagemeiger and Blair, 1997) however, the Common Kingfisher (Alcedo atthis) is a usual resident. Common Kingfisher is a generalist fish-eating predator, foraging on fish-prey with sizes from 30 to $100 \mathrm{~mm}$ length (fork length) (Cramp 1985). Atlantic salmon parr (i.e., age-0 salmons, ranging from ca. 30 to $120 \mathrm{~mm}$ ) is one of the preys which falls within kingfishers' food intake ranges.

The Common Kingfisher in Europe suffered a moderate decline between the decades of 1970-1990 (Tucker and Heath, 1994). Although the species was broadly stable between 1990 and 2000, its population has not yet reached the numbers that preceded its decline and, consequently, it is evaluated as depleted (Tucker and Heath, 2004). Previous studies on the diet of this species report variable composition, with salmonids contributing between 2 and 55 percent (Hallet, 1977; Čech and Čech, 2011). In this scenario, a better understanding of kingfishers' diet and their preferred food resources could be an important key in conservation management plans (Cowx, 2003).

This study uses data on both the kingfisher population and the salmon population for an entire river catchment to assess the impact of this piscivore on an important fish species.

\section{MATERIALS AND METHODS}

The study was carried out in two nearby rivers from southern England, the River Frome and the Piddle. Common Kingfisher nests were searched from May to June during the breeding 


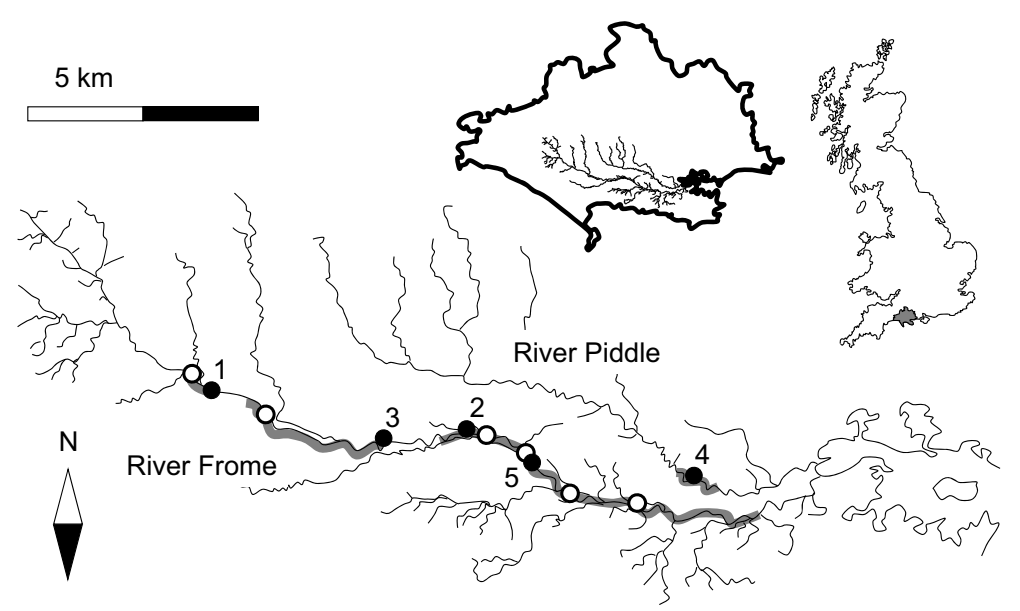

\section{Figure 1}

Study area showing walk-surveys (thick line), kingfishers' nest (black dots indicate active nest; inactive or predated indicated for white dots). Numbers of nests correspond to those in Table I.

season of 2011. In total, walk-over surveys of $50 \mathrm{~km}$ of the River Frome $\left(70 \mathrm{~km}\right.$ and $454 \mathrm{~km}^{2}$ basin) and Piddle (40 km and $184 \mathrm{~km}^{2}$ ) were completed searching for active nests, which were confirmed by the presence of breeding adults or fresh faeces in the entrance of the tunnels where the nests were found (Figure 1). The rivers used in this study are both chalk rivers, have similar hydro-morphological features and native populations of kingfishers and Atlantic salmon.

The upper reaches of the rivers were not searched for kingfisher nests as these locations were unlikely to have suitable banks necessary for successful breeding (Cramp, 1985; Vilches et al., 2012b).

Overall, five kingfisher nests were found and at the end of the breeding season in late August kingfisher's pellets (rest of food composed by fish bone pieces and scales) were taken from these. The pellets were taken from each nest with a 1-m rake, stored in plastic bags until they were analysed in a laboratory. In order to both clean fish and take out soil remains, the pellets were washed with water using a sieve $(0.5 \mathrm{~mm}$ mesh) in the laboratory and the fish bones were sorted from the entire sample. Bones (only those with diagnostic value as shown by Feltham and Marquiss, 1989; Reynolds and Hinge, 1996; Miranda and Escala, 2002; Prenda et al., 2002; Davies et al., 2004) were separated into species-size categories based on their form and size. We used pharyngeal arcs, pelvic, maxillary and dentary bones (used to classify non-salmonid fish) and atlas vertebrae (used to determine salmonids) as diagnostic bones.

To gain an estimate of the amount of food being delivered to brood on a daily basis, we recorded feeding activity at three of the nests. We used a digital video camera (Panasonic SDR-H40) hidden and placed in front of each nest, recording from sunrise to sunset. Three recording sessions were carried out at each nest (Nest 1 recorded on June 16, 23 and 25, Nest 3 on June 28 and 30 and July 2, and Nest 4 on June 21 and 20, and July 21) once the adults had been feeding chicks for several days (at least four days from the first delivery activity observed in adults), as feeding activity is low immediately after the eggs hatch (Cramp, 1985). The number of individual events of delivering food to each nest was counted within each hour by replaying the video footage in the laboratory. Since kingfishers only deliver one fish at a time, the number of events equate to the numbers of fish delivered to the brood. From this data, a fitted function was generated by means of a polynomial regression. $P$-value, based on an $F$ test, gives the significance of the fit. We calculated the amount of prey that parents delivered to a nest in one day from this function. All statistical procedures were performed with PAST software package (Hammer et al. 2001).

To assess the impact of Common Kingfishers on salmon parr population (age-0, here fish born in 2011) we estimated fish densities only considering the kingfishers' fish-prey consumed ranges (i.e., from 30 to $100 \mathrm{~mm}$ ). This work was done only for the River Frome. Densities 
Table I

Number and proportion of species consumed by Common Kingfisher found in the studied nests.

\begin{tabular}{|l|c|c|c|c|c|c|c|c|c|c|c|c|}
\hline $\begin{array}{l}\text { Species } \\
\text { Barbatula } \\
\text { barbatula }\end{array}$ & & & 1 & 0.3 & 1 & 0.2 & 4 & 0.7 & & & 6 & 0.3 \\
\hline Cottus gobio & 124 & 32.5 & 51 & 13.6 & 83 & 16.9 & 126 & 22.5 & 125 & 24.2 & 509 & 21.9 \\
\hline $\begin{array}{l}\text { Gasterosteus } \\
\text { aculeatus }\end{array}$ & 83 & 21.7 & 26 & 6.9 & 53 & 10.8 & 115 & 20.5 & 42 & 8.1 & 319 & 13.7 \\
\hline $\begin{array}{l}\text { Squalius } \\
\text { cephalus }\end{array}$ & & & & & 25 & 5.1 & 1 & 0.2 & & & 26 & 1.1 \\
\hline Perca fluviatilis & & & & & 7 & 1.4 & & & & & 7 & 0.3 \\
\hline $\begin{array}{l}\text { Phoxinus } \\
\text { phoxinus }\end{array}$ & 155 & 40.6 & 297 & 79 & 247 & 50.2 & 281 & 50.2 & 302 & 58.4 & 1282 & 55.1 \\
\hline Rutilus rutilus & & & & & 33 & 6.7 & 1 & 0.2 & & & 34 & 1.5 \\
\hline Salmo salar & 4 & 1.1 & & & 7 & 1.4 & 13 & 2.3 & 34 & 6.6 & 58 & 2.5 \\
\hline Salmo trutta & 14 & 3.6 & & & 9 & 1.8 & 17 & 3.0 & 14 & 2.7 & 54 & 2.3 \\
\hline $\begin{array}{l}\text { Scardinius } \\
\text { erythrophthalmus }\end{array}$ & 2 & 0.5 & & & 26 & 5.3 & 2 & 0.4 & & & 30 & 1.3 \\
\hline Tinca tinca & & & & & 1 & 0.2 & & & & & 1 & 0.0 \\
\hline Total & 382 & 100 & 375 & 100 & 492 & 100 & 560 & 100 & 517 & 100 & 2326 & 100 \\
\hline
\end{tabular}

of salmon parr $\left(n \cdot m^{-2}\right)$ were estimated for the kingfishers' territories (where the nests were found) by multiple shock-catch depletion (Seber, 1982) of $100 \mathrm{~m}$-length sections close to the nests (river width at each section ranged between $6.2 \mathrm{~m}$ and $11.4 \mathrm{~m}$ ).

The salmon parr population size was estimated from a catchment wide mark-recapture (Lincoln-Peterson method, Seber, 1982). For that, we tagged 5851 salmon parr throughout the catchment with passive integrated transponder (PIT) tags during September 2011. They were recaptured as smolts during the spring of 2012. All population estimates were made from data collected in September of 2011 when salmon parr reaches a maximum size of $120 \mathrm{~mm}$ (fork length), although during the period when kingfishers feed their broods (from May to July) this size would reach no more than $100 \mathrm{~mm}$, so we have assumed that all the salmon parr were potential prey for the kingfisher.

Fish captures and handling were performed by trained personnel. Thus, no adverse effects were caused on the wildlife and all fish recovered fully from the anaesthetic. Moreover, all field procedures complied with animal use and care regulations of Europe and UK.

\section{RESULTS}

Eleven kingfisher nests were found in 50 km (River Frome, 48.6 km; Piddle, 1.4 km), although only six showed breeding activity, being the other five either nests from previous years or predated (Figure 1).

From the pellet analysis we found 11 fish prey species (Table I): Stone Loach (Barbatula barbatula), Bullhead (Cottus gobio), Three-spined Stickleback (Gasterosteus aculeatus), Chub (Squalius cephalus), Perch (Perca fluviatilis), Minnow (Phoxinus phoxinus), Roach (Rutilus rutilus), Rudd (Scardinius erythrophthalmus), Brown Trout (Salmo trutta), Atlantic salmon (Salmo salar) and Tench (Tinca tinca). The most abundant prey was the Minnow (55.1\%) and the least one was the Tench $(0.04 \%)$. Atlantic salmon intake was $2.5 \%$ (range: $0.0-6.6 \%$ ).

Kingfishers consumed salmons with a size ranging from 30 to $100 \mathrm{~mm}$-total length, with the most consumed size ranging from 80 to $90 \mathrm{~mm}$-total length (Figure 2).

Fish-provisioning to brood was not constant across the day, but fitted a quadratic function with peaks of prey-delivery to the nest at the beginning and end of the day (Figure 3). The amount of prey that parents delivered to a nest in one day was $62.6 \pm 0.2$ (SE). Kingfishers 


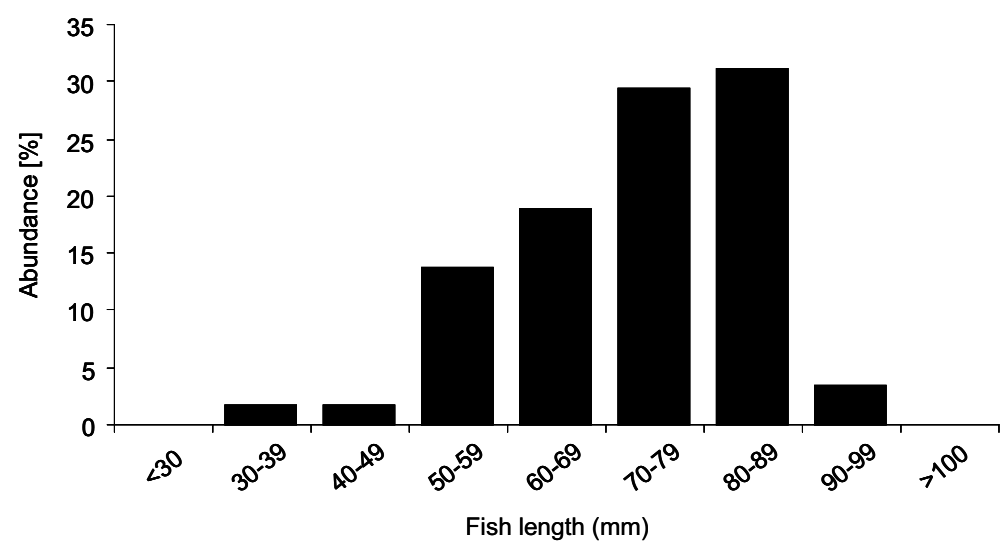

\section{Figure 2}

Salmon-size categories consumed by kingfishers ( $n=58$ atlas fish bones). Fish lengths obtained from bone lengths according to Feltham and Marquiss (1989).

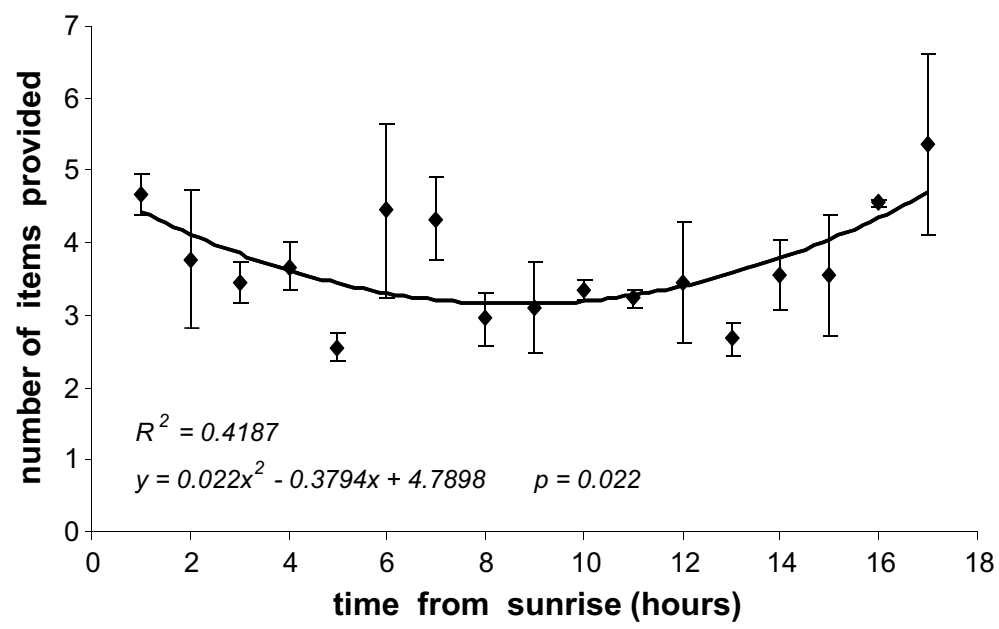

\section{Figure 3}

Daily activity feeding rates whit error bars (show Interval of Confidence 95\%). Coefficient of determination $\left(R^{2}\right)$ and $p$ value of fitted function of data are shown.

feed their brood until they reach an age of 23 to 27 days (Cramp, 1985). Considering a period of 25 days of stay in the nest the amount of fish provided to a nest whilst the chicks remain inside it is 1566. As the species has on average 2.2 broods in a year (Newton, 1989), it can be extrapolated that a single pair will fish 3445 fishes in a year, during the period when the chicks are into the nest. From the pellet analysis we obtained that the salmon intake was $2.5 \%$ of the total number of prey items, (see above and Table I for the details), which represents about 86 salmon parr (227 in a nest with $6.6 \%$ of salmon intake) consumed by a kingfisher couple during a breeding season and whilst their chicks remain into the nest.

The total number of 0-group salmon parr present in the River Frome during September 2011 was $63900 \pm 5500(95 \% \mathrm{Cl})$. Density $\left(\mathrm{n} \cdot \mathrm{m}^{-2}\right)$ of salmon parr situated near the nests ranged from 0.19 to 0.53 .

\section{DISCUSSION}

We studied here the diet of a Common Kingfisher population breeding in rivers from south England with Atlantic salmon populations. We also studied the feeding rate pattern of adults to chicks during the period when brood remains inside the nest. Overall, we used these data 
to assess the impact of the Common kingfishers on such Atlantic salmon population during the kingfishers' breeding season.

With more than a 55\%, the Minnow was the most consumed prey. This is also one of the most abundant fish within the River Frome (Mills, 1987), thus indicating that kingfishers tended to eat the most frequent prey, as stated in other works (Hallet, 1977; Raven, 1986; Vilches et al., 2012a).

The consumption of salmons reached a $2.5 \%$ of the total and, therefore, it tended to be rather marginal both in relative and absolute terms. Since the amount of fish estimated was 1566 preys, 86 salmon parr per pair during the period when the chicks are in the nest and assuming 2.2 broods/year. But this value could be overestimated considering the period of nest recording (a close period) to calculate this value, and taking into account that this estimation depend on the number of chicks in the nest and the size of fish preyed and delivered to the chicks. The size of preys changes during the breeding period, being greater at the end, and the number of delivered fish changes depending on the time during the breeding period. Swanberg (1952, in: Raven 1986) stated that a kingfisher brood can consume 1000 fish, and other researchers suggest that it is less, 400-800 fish (M. Čech, personal communication). From the number of fishes identified from osseous remains of the studied nests, lower value was 375 recuperated fish in the smaller nest. Considering this interval of values, an upper (86 salmon parr from 1566 fish) and lower (9 salmon parr from 375 fish) limits has been considered.

In the River Frome the amount of nests found in total was six which is equivalent to a density of 0.12 pair. $\mathrm{km}^{-1}$, considering a length of $48.6 \mathrm{~km}$ of river, which allows us to assess an intake interval rate between 10.3 and 1.1 salmon parr. $\mathrm{km}^{-1}$ (or $502-52$ salmon parr for the $48.6 \mathrm{~km}$ ), which means an impact between 0.80 and $0.08 \%$ over the salmon parr population. Besides, the estimates of the salmon population size are done later than the feeding season (in September), but since there cannot be less salmon earlier in the year we are expressing the impact of the kingfishers as a maximum, and this is still consistent with our view that the impact is not significant. Therefore, and considering all the above, the kingfisher had a presumably negligible impact over the salmon population.

In rivers with larger salmon populations, the salmon may be more frequently consumed up to be even a relevant/key prey for the kingfishers. However, even in these cases the impact may be negligible, since kingfishers would be foraging on a small fraction of salmon population, because the species is a generalist predator which just preys upon the most abundant and available fish (Vilches et al., 2012a). Exceptions to this rule may be the cases where a single couple could have a high impact over isolated fish-prey populations, as found in other piscivorous birds (Cowx, 2003). Also we should take into account that we did not consider the impact due to chicks' feeding pressure outside the nestling period not the impact due to adults' diet, or diet during the non-breeding period in case of resident birds or birds that arrive in an area as migrants or winter visitors (Arizaga et al., 2010).

A final consideration would be those cases of rivers with higher bird densities. According to the bibliography the highest density for kingfishers is 1.2 pairs $\cdot \mathrm{km}^{-1}$ (Chandler and Llewellyn, 2010 ), which in our study river may have an impact of $8.5 \%$ over salmon population. Unfortunately, no historical data on kingfisher densities are available for the River From, so we cannot obtain a more accurate estimation over the "potential" impact that the kingfisher may have. Anyhow, in general the density of kingfishers in Europe fall within an interval from less than 0.1 to 0.2 pair $\cdot \mathrm{km}^{-1}$ (Cramp, 1985; Moreno-Opo, 2003; Vilches et al., 2012b) so, in conclusion, it can be well assumed a marginal impact of kingfishers over the salmon population, at least in the case of the River Frome in England.

\section{ACKNOWLEDGEMENTS}

The author wishes to thank to William Beaumont (GWCT) and Phil Davison (CEFAS) who provided collection material used for pellets identification. Sarah Williams from the DWT who help us in locating kingfishers nest. The Asociación de Amigos de la Universidad de Navarra, 
the Caja de Ahorros de Navarra, the Fundación Territorio y Paisatje of Caixa Catalunya and the Government of Navarra funded this work. Special thanks go to Edward Noyes, Dominic Stubbing and Luke Scott who assisted during the field work.

\section{REFERENCES}

Arizaga J., Mendiburu A., Alonso D., Cuadrado J.E., Jauregi J.I. and Sanchez J.M., 2010. Common Kingfishers Alcedo atthis along the coast of northern Iberia during the autumn migration period. Ardea, 98, 161-167.

Britton J.R., Harvey J.P., Cowx I.G., Holden T., Feltham M.J., Wilson B.R. and Davies M.J., 2003. Key factor analysis to assess cormorant depredation on inland fisheries in the UK. In: Cowx I.G. (ed.), Interactions between fish and birds: Implication for management, Fishing News Books, Blackwell Science, Oxford, 14-27.

Carss D.N. and Marquiss M., 1999. Skeletons in the cupboard? Quantifying bird predation on Atlantic salmon: atlas vertebra: length equations revisited. J. Zool., 248, 272-276.

Čech M. and Čech P., 2011. Diet of the Common Kingfisher (Alcedo atthis) in relation to habitat type: a summary of results from the Czech Republic. Sylvia, 47, 33-47.

Čech M. and Vejrík L., 2011. Winter diet of Great Cormorant (Phalacrocorax carbo) on the River VItava: estimate of size and species composition and potential for fish stock losses. Folia Zool., 60, $129-142$.

Chandler D. and Llewellyn I., 2010. Kingfisher. New Holland Publishers, London.

Cramp S., 1985. Handbook of the birds of Europe, the Middle East and North Africa: the birds of the Western Palearctic. Volume IV: Terns to Woodpeckers. Oxford University Press, Oxford, $960 \mathrm{p}$.

Cowx I.G. (ed.), 2003. Interactions between fish and birds: Implication for management. Fishing News Books, Blackwell Science, Oxford, $348 \mathrm{p}$.

Davies C., Shelley J., Harding P., Mclean I., Gardiner R. and Peirson G. (eds.), 2004. Freshwater Fishes in Britain - the species and their distribution. Harley Books, Colchester, $176 \mathrm{p}$.

Feltham M.J., 1990. The diet of red-breasted merganser (Mergus serrator) during the smolt run in N.E. Scotland: the importance of salmon (Salmo salar) smolts and parr. J. Zool., 222, 285-292.

Feltham M.J., 1995. Predation of Atlantic salmon, Salmo salar L., smolts and parr by red-breasted mergansers, Mergus serrator L., on two Scottish rivers. Fisheries Manag. Ecol., 2, 289-298.

Feltham M.J. and Marquiss M., 1989. The use of the first vertebrae in separating and estimating the size of trout (Salmo trutta) and salmon (Salmo salar) in bone remains. J. Zool., 219, 113-122.

Friedland K.D., Reddin D.G. and Cocik J.F., 1993. Marine survival of North American and European Atlantic salmon: effects of growth and environment. ICES J. Mar. Sci., 50, 481-492.

Hagemeiger W.J.M. and Blair M.J., 1997. The EBCC Atlas of European Breeding Birds: their distribution and abundance. Poyser, London, $903 \mathrm{p}$.

Hallet C., 1977. Contribution a l'etude du regime alimentaire du Martin-Pêcheur (Alcedo atthis) dans la Vallée de la Lesse. Aves, 14, 128-144.

Hammer Ø., Harper D.A.T. and Ryan P.D., 2001. PAST: Paleontological statistics software package for education and data analysis. Palaeontologia Electronica, 4, 9.

Mills C.A., 1987. The life history of the minnow Phoxinus phoxinus (L.) in a productive stream. Freshwater Biol., 17, 53-67.

Miranda R. and Escala M.C., 2002. Guía de identificación de restos óseos de los Ciprínidos presentes en España. Serie Zool., 28, 1-241.

Moreno-Opo R., 2003. Martín Pescador Común, Alcedo atthis. In: Martí R. and Del Moral J.C. (eds.), Atlas de las aves reproductoras de España, DGCN-SEO/BirdLife, Madrid, 342-343.

Newton I. (ed.), 1989. Lifetime reproduction in birds. Academic Press, London.

Prenda J., Arenas M.J., Freitas D., Santos-Reis M. and Collares-Pereira M.J., 2002. Bone Length of Iberian Freshwater Fish, as a Predictor of Length and Biomass of Prey Consumed by Piscivores. Limmetica, 21, 15-24.

Raven P., 1986. The size of minnow prey in the diet of young Kingfisher Alcedo atthis. Bird Study, 33, 6-11. 
Reynolds S.J. and Hinge M.D.C., 1996. Foods brought to the nest by breeding Kingfishers Alcedo atthis in the New Forest of southern England. Bird Study, 43, 96-102.

Russell I.C., Dare P.J., Eaton D.R. and Armstrong J.D., 1996. Assessment of the problem of fish eating birds in inland fisheries in England and Wales. Directorate of Fisheries Research, Lowestoft, $48 \mathrm{p}$.

Seber G.A.F., 1982. The Estimation of Animal Abundance. Griffin, London.

Tucker G.M. and Heath M.F., 1994. Birds in Europe: their Conservation Status. Birdlife International, Cambridge, $374 \mathrm{p}$.

Tucker G.M. and Heath M.F., 2004. Birds in Europe: population estimates, trends and conservation status. BirdLife International, Cambridge, 374 p.

Vilches A., Miranda R. and Arizaga J., 2012a. Fish prey selection by the Common Kingfisher Alcedo atthis in Northern Iberia. Acta Ornithol., 47, 167-175.

Vilches A., Miranda R., Arizaga J. and Galicia D., 2012b. Habitat selection for breeding Common kingfisher (Alcedo atthis L.) in rivers from northern Iberia. Ann. Limnol. - Int. J. Lim., 48, 289-294.

Wilson B.R., Feltham M.J., Davies J.M., Holden T., Cowx I.G., Harvey J.P. and Britton J.R., 2003. A quantitative assesment of the impact of Goosander, Mergus merganser, on salmonid population in two upland rivers in England and Wales. In: Cowx I.G. (ed.), Interactions between fish and birds: Implication for management, Fishing News Books, Blackwell Science, Oxford, 119-135.

Winfield I.J., Crawshaw D.H. and Durie N.C., 2003. Management of the cormorant, Phalacrocorax carbo, and endangered whitefish, Coregonus lavaretus, populations IF Haweswater, UK. In: Cowx I.G. (ed.), Interactions between fish and birds: Implication for management, Fishing News Books, Blackwell Science, Oxford, 335-344. 